\title{
2.REDD+の仕組み
}

\section{Framework of REDD+}

\section{松本 光朗* Mitsuo MATSUMOTO}

\begin{abstract}
The overview of REDD + is presented to facilitate discussion of the special issue on REDD + . REDD + is an international program intended to mitigate $\mathrm{CO}_{2}$ emissions by conserving forests in developing countries. After 10 years' negotiation, the Paris agreement encouraged to take action to implement and support for REDD + in 2017. The scientific and historical background of the REDD + is shown at first, then the framework of REDD + is illustrated. National Forest Monitoring System (NFMS) and Forest Reference Emission Levels and Forest Reference Levels (FREL/FRL) are focused as important technical issues of REDD + . Remote sensing is expected as a key technique for transparent monitoring of forest carbon. While methodologies for REDD + have reached the implementation phase, negotiation on REDD + finance is ongoing under the Green Climate Fund.
\end{abstract}

\section{1.はじめに}

2015年，気候変動枠組条約 (UNFCCC) の第21回締 約国会議において，気候変動対策の新たな枠組みとし てパリ協定が合意された（UNFCCC，2015）。パリ協定 は，途上国を含む全ての国に削減の義務づけ，温度上 昇を $2{ }^{\circ} \mathrm{C}$ 以内に抑制するなど，大きく踏み込んだ内容 となった。さらに, 森林保全による緩和策である REDD+の実施と支援の推奨が記されたことは特筆す べきである。

REDD+は, 森林保全により温室効果がスの削減が できれば，その量に応じて資金等のインセンティブが 得られるという社会経済的な制度である。そのため, 広大な森林を対象に信頼性と透明性の高い排出削減量 の評価方法が求められ，リモートセンシングは REDD＋制度を支える重要な技術と位置付けられてい る。

本報告は, 特集「REDD+におけるリモートセンシン グへの期待」において, 以降の研究報告の背景となる ように, REDD+が生まれてきた経緯や要点を解説し, その現状を紹介する。

\section{REDD+の概要}

$\mathrm{REDD}+$ は, 途上国の森林保全活動を通して, 温室効

*国立研究開発法人 森林研究・開発機構 森林総合研究所 関西支所

「写真測量とリモートセンシング」VOL. 56, NO. 5, 2017
果ガスの排出削減・吸収増加を進める温暖化緩和活動 の一つである。REDD+とは, Reducing Emissions from Deforestation and forest Degradation and the role of conservation, sustainable management of forests and enhancement of forest carbon stocks in Developing countries を表す略語であり，前段の「途 上国の森林減少・劣化に由来する二酸化炭素の排出の 削減」の英語表記の頭文字である「REDD」に，その後 に加えられた活動「森林保全, 持続可能な森林経営, 森林炭素蓄積の増強」を指す「十」が付け加えられて 作られた。

ここで, 森林減少とは森林から農地や市街地など他 の土地利用への変化を意味する。一方, 森林劣化とは 土地利用は変化しないものの，伐採などの攪乱により 森林の量や質が劣化することを意味する。また，森林 保全や持続可能な森林経営, 森林炭素蓄積の増強とは, 森林減少や劣化を回避した森林の健全な経営や, 植林 による二酸化炭素の吸収を意味する。

REDD+は, 森林減少・劣化の抑制や保全などの活動 を行い，それにより温室効果がス排出を削減あるいは 吸収量を増加できれば，その成果量に応じて経済的な インセンティブ (資金) が得られるという，結果支払 いのポジティブ・インセンティブという点が特徵であ る。これは, 森林減少の多くは農地や都市などの開発 が主因であり，開発よりも森林を維持した方が経済的 に有利になれば森林減少は抑制される，という社会経 済的視点に立つものである。 
さらに, REDD+は森林保全活動を通して生物多様 性保全や地域経済や地域住民への貢献といったコベネ フィット (副次利益) をもたらすことが期待されてお り, これが他の緩和策とは異なる特徵となっている。

\section{3. 科学的背景と国際交渉の経緯}

IPCC 第 4 次評価報告書 (IPCC, 2007a) は, $\mathrm{CO}_{2}$ 排 出量の 8 割は化石燃料・セメントによる排出であるが, 残りの 2 割は森林減少による排出であるとした。また, 世界農業機関（FAO）は，ブラジル，インドネシア， 熱帯アフリカに扔いて森林減少が激しいことを示した （FAO，2006)。国別に見れば，2000～2005年における 森林減少の世界合計のうち，ブラジルとインドネシア の 2 国で世界の $60 \%$ 占めていた。その後, IPCC 第 5 次評価報告書（IPCC，2012）では，2000年以降では森 林減少による排出は全体の 1 割に減ったことが報告さ れたが，依然として大きな排出源であることは間違い ない。

スターン・レビュー（Stern，2007）は，森林減少の 抑制は温室効果がスを削減する上で費用対効果が高い とした。また, IPCC 第 4 次評価報告書（IPCC， 2007 b) は, $\mathrm{CO}_{2} 1$ トン当たり100米ドル以下のコストにおけ る削減ポテンシャルの65\%は熱帯地域にあり，50\%は 森林減少からの排出を削減することで達成されうると している。このように，科学的視点からは森林減少 . 劣化による排出の削減の必要性が，経済的視点からは 低コスト性が，REDD+の推進の基盤となっている。

しかし，その当時の京都議定書の削減目標は先進国 のみの約束であり, 途上国の森林減少を止める仕組み は持たなかった。そのため, 2005年にカナダ・モント リオールで開かれたCOP11において, 森林減少による 温室効果がス排出を削減する「森林減少の回避」が提 案された。このコンセプトは世界から受け入れられ， 2007年インドネシア・バリで開かれたCOP13では REDD として森林減少・劣化の削減の必要性が強調さ れた。その後十に当たる活動が加わり，2010年メキシ コ・カンクンで開催されたCOP16において，活動の定 義を含めた REDD+の大枠について合意に至った（カ ンクン合意)。その後 REDD+の議論・国際交渉が続け られ，2013年ポーランド・ワルシャワでの COP19で技 術的議論はほぼ終了した。その結果は「REDD+のため のワルシャワ枠組み」と呼ばれる。さらに，2015年フ ランス・パリでのCOP15でパリ協定に REDD+の実
施と支援の推奨が記され，これにより REDD+の本格 実施に至った。

\section{REDD+の仕組み}

REDD十のルールはカンクン合意 (UNFCCC, 2010) や REDD+のためのワルシャワ枠組み（UNFCCC, 2013）(以下，ワルシャワ枠組みと略称)を中心に複数 の COP 決定から形作られている。ここでは, 要点をと りまとめ, REDD+の仕組みの全体像を描く。

\section{1 目的と活動の定義}

カンクン合意は, 締約国は団結して森林被覆及び炭 素の損失を低減, 停止, 反転することを目的とすべき ことを確認し, 途上国各国に対して森林減少からの排 出の削減, 森林劣化からの排出の削減, 森林炭素蓄積 の保全, 持続可能な森林経営, 森林炭素蓄積の強化, という活動の実施を奨励した。これら5つの活動が REDD+の活動として定義された。

\section{2 実施に関わるガイダンス}

カンクン合意は, 実施に関わるガイダンスとして, 環境十全性と整合し森林等生態系の多面的機能への配 慮, 国家主権の尊重, 結果ベース, 持続可能な森林経 営の促進等を提示した。

\section{3 途上国への要請}

カンクン合意は, 途上国は, 国家戦略あるいは行動 計画, 森林参照 (排出) レベル (FREL/FRL), 国家森 林モニタリングシステム，セーフガードのための情報 システム等の策定・作成を求めた。また，森林減少 · 劣化の原因, 土地所有, 森林がバナンス, ジェンダー, セーフガード，先住民・地域コミュニティーを含む関 係者の参加等への対処についても求めた。

\section{4 フェーズド・アプローチ}

カンクン合意は, REDD+の取組みを国情, 能力や将 来性, 受ける援助の程度により, 第 1 フェーズ (準備 段階), 第 2 エェズ (実施段階), 第 3 フェーズ (完 全実施段階）と段階的に実施するとした（カンクン合 意)。これはフェーズド・アプローチと呼ばれる。特に 第 1 フェーズでは能力開発など先進国からの支援が求 められる。 


\section{5 国家森林モニタリングシステム (NFMS)}

国家森林モニタリングシステム (NFMS) とは, 国・ 準国レベルでの森林からの温室効果ガス吸排出量を観 測するシステムであり，最新の気候変動に関する政府 間パネル（IPCC）のガイダンスに準拠し，リモートセ ンシングと地上調査の組合せから吸排出量が推定され る（UNFCCC，2009b）。また，ワルシャワ枠組みは， NFMS を構築するには透明で期間を通じて一貫性を 持ち, MRV (後述)に適したデー夕と情報を提供しな ければならない,とした。

ここで，国・準国レベルという観測スケールの記述 は重要である。REDD+活動が小さな地域で行われた 場合, その地域内では森林保全により排出削減できて も，地域外で森林伐採等による排出が発生してしまう ことがある (displacement)。これを排除するために, REDD十の活動の規模を国レベル，あるいはそれに準 じたレベルであることが求められた。ただし，準国レ ベルであっても将来的に国レベルとなる見通しが求め られる。

また,リモートセンシングと地上調査の組合せという 具体的な方法が，国際合意に示されていることは興味 深い。資金に直結するため, 削減量推定には信頼性と透 明性が求められ，リモートセンシングは欠かせない技 術として取り上げられた。また, 森林の面的変化だけで はなく, 森林炭素重量の増減を把握する必要があるこ とから, 地上調査も合わせて求められたと理解できる。

これをふまえて, REDD+での吸排出量の推定方法 の基本は以下のように説明される（REDD 研究開発セ ンター, 2012)。

$$
C_{t}=\sum_{i=1}^{n}\left(A_{i} \times C_{i}\right)
$$

ここで， $C_{t}$ はある時点 $t$ における炭素蓄積合計 $(t-C), A_{i}$ は $i$ 番目の森林夕イプの占める面積 (ha), $C_{i}$ は $i$ 番目の森林夕イプがもつ単位面積当たりの炭 素蓄積 $(t-C / h a)$ である。

$$
\Delta C=\frac{C_{t_{2}}-C_{t_{1}}}{t_{2}-t_{1}}
$$

ここで, $\Delta C$ は吸排出量 $\left(t-C /\right.$ 年) $, C_{t 2}, C_{t 1}$ はそれ ぞれ時点, $t_{2}, t_{1}$ (年) における合計炭素蓄積 $(t-C)$ で ある。

\section{6 森林参照（排出）レベル（FREL/FRL）}

森林参照（排出）レベル (FREL/FRL) とは, $\mathrm{CO}_{2}$

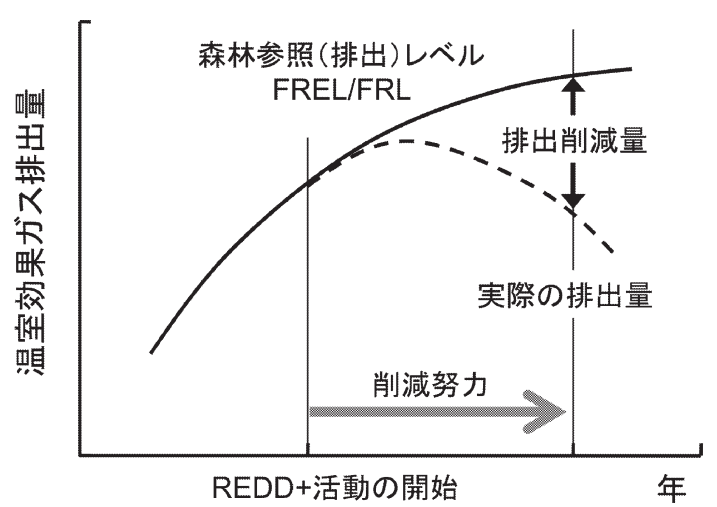

図 1.REDD+の排出削減量の考え方

トン/年で表される各国の活動を評価するベンチマー クであり(UNFCCC, 2011)，この FREL/FRL と実際 の排出量の差が活動による排出削減量となる（図 1)。

各国は過去のデータと国情による調整を考慮し, 透 明な方法でFREL/FRLを開発する（UNFCCC, 2009)。また, ワルシャワ枠組みは FREL/FRLについ て技術評価のガイドラインと手順を規定した。各国が 開発し UNFCCC 事務局に提出された FREL/FRL は 技術評価を受け，情報提出がイドラインとの整合性評 価, FREL/FRLの策定・将来の改善を視野にいれた促 進的な技術情報交換が行われた上で承認される。

\section{7 セーフガード}

カンクン合意は, セーフガード (安全措置) につい て, 森林ガバナンス, 先住民等の知識・権利の尊重, 天然林や生物多様性の保全との整合, 排出の反転や移 転の抑制など，促進・支援すべき 7 項目を提示した。 セーフガードとは, REDD+の活動が社会や環境など 別の側面で生じる恐れがある負の影響を予防する措置 を意味する。なお，途上国はセーフガード概要情報を 活動実施開始後に国別報告書または Web プラット フォーム「REDD+のためのリマ情報ハブ」へ提出し, 掲載される。

\subsection{MRV（観測・報告・検証）}

REDD+活動に限らず，UNFCCC での緩和活動の 評価には, MRV (測定・報告・検証) が求められる。 ワルシャワ枠組みは, REDD+での MRV の技術的方 法についてNFMS と FREL/FRLに関する手法や デー夕の一貫性を強調した。さらに, MRVのデータや 情報は途上国の隔年更新報告書 (BUR) 及び技術附属 
書を通じ提出し，技術専門家チームが技術分析を行う とした。

\section{9 資 金}

ワルシャワ枠組みは, 活動結果に基づく資金を受け るには, カンクン合意の要素を全て満たし，活動が完 全に MRV され，最新のセーフガード概要情報を事前 に提出する必要があるとした。また，資金に関しては 緑の気候基金（Green Climate Fund, GCF）に役割が あることを確認し，結果支払いについての検討におい ては，UNFCCC 合意の方法論を適用するよう依頼し た。つまり，以降, REDD+についての資金の支払い方 法等の検討については GCF に委ねられた。

\section{REDD+の現状}

\section{1 活動と資金の現状}

2013年にワルシャワ枠組みにより技術的な指針が明 確になってから，途上国各国は積極的に REDD+体制 の構築を進めてきた。FAO（2017）によれば，2017年 初頭の段階で25力国から26件の FREL/FRL が技術評 価に提出され，9 件の技術評価報告がなされた。さら に，ブラジルなど 4 国が排出削減量を報告し，ブラジ ルはすでに排出削減量の技術分析を終了した。このよ うに，多くの国でREDD+は進み，先進的な国では本 格実施に近づいている。

その一方，資金の問題はまだ遅れており，Green Climate Fund (GCF) において REDD+の結果支払い 方法について検討されているところである。

\subsection{UNFCCC 以外の REDD+活動}

REDD+活動は UNFCCCの中だけで行われている わけではない。UNFCCCの外では, 世界銀行による森 林炭素パートナーシップ基金 (FCPF) やブラジル開発 銀行が運営するアマゾン基金など，各国により自主的 な活動を進められている。

日本は途上国における排出削減策として二国間クレ ジット制度（JCM）を進めており，その中でREDD+ プロジェクト実施のためのガイドラインを開発してい る。2017年 9 月末現在, 日本は JCM に関して17カ国と 合意しているが(新メカニズム情報プラットフォーム, 2017), その半数はラオス, カンボジアといった森林国 であり, JCM の中で REDD+を進めることが期待さ れている。

\section{6.おわりに}

ワルシャワ枠組みとパリ協定により REDD+は本 格実施の段階に入り, リモートセンシングを含む森林 炭素モニタリングはすでに多くの国で実行されるよう になった。しかし，その次には資金というより現実的 な課題が待ち構えており, 今 GCFにおいて議論され ているところである。資金の議論は緩和活動のみなら ず，モニタリングの実行など技術面にも影響を及ぼす 可能性を残している。関係者は, REDD+の推進を進め るともに, 資金に関する動向もフォローしていく必要 があろう。

\section{引用文献}

IPCC, 2007a, Climate Change 2007: The Physical Science Basis, Cambridge University Press.

IPCC, 2007b, Climate Change 2007: Mitigation of Climate Change, Cambridge University Press.

IPCC, 2013, Climate Change 2013: The Physical Science Basis, Cambridge University Press.

FAO, 2006, Global Forest Resources Assessment 2005, FAO Forestry Paper 147.

FAO, 2017, From reference levels to results reporting: REDD + under the UNFCCC, Forests and Climate Change Working Paper, 15.

REDD 研究開発センター, 2012, REDD + Cookbook, 森林総合研究所 REDD 研究開発センター.

新メカニズム情報プラットフォーム, 2017. JCM の基 本コンセプト, http://www.mmechanisms.org/ index.html.

Stern, N., 2007, Identifying the costs of mitigation, In Stern review on the economics of climate change, Cambridge University Press, 211-238.

UNFCCC, 2009. Decision 4/CP. 15, FCCC/CP/2009/ 11/Add. 1. 11-12, UNFCCC.

UNFCCC, 2010. III-C, Decision 1/CP. 16, FCCC/CP/ 2010/7/Add. 1, 12-14, UNFCCC.

UNFCCC, 2011. Decision 12/CP. 17, FCCC/CP/ 2011/9/Add. 2, 16-18, UNFCCC.

UNFCCC, 2013. Decision 9-16/CP. 19, FCCC/CP/ 2013/10/Add. 1, UNFCCC.

UNFCCC, 2015. Paris agreement, UNFCCC. 